PACS: $61.41 .+\mathrm{e}, 62.20 . \mathrm{fg}$

\title{
REGULARITIES OF LOW-TEMPERATURE DEFORMATION AND FRACTURE OF POLYIMIDE FILMS OF KAPTON H TYPE OF DIFFERENT THICKNESS
}

\author{
DViktory A. Lototskayaa,*, (D) Leonid F. Yakovenko ${ }^{a}$, DVgeniy N. Aleksenko ${ }^{a}$, \\ Vyacheslav V. Abraimov ${ }^{b}$, Wen Zhu Shaob \\ ${ }^{a} B$. Verkin Institute for Low Temperature Physics and Engineering of National Academy of Science of Ukraine \\ Avenue Nauky, 47, Kharkov, 61103, Ukraine \\ Corresponding Author: lototskaya@ilt.kharkov.ua \\ ${ }^{b}$ Harbin Institute of Technology \\ Harbin, the People's Republic of China
}

Received October 5, 2020; last revised November 3, 2020; accepted November 6, 2020

\begin{abstract}
The mechanical characteristics (limit of forced elasticity $\sigma_{\text {forc}}$, rupture stress $\sigma_{\mathrm{r}}$, relative deformation to rupture $\varepsilon_{\mathrm{r}}$ ) of polyimide films of kapton $\mathrm{H}$ type under uniaxial tension conditions along the direction of drawing in the temperature range (4.2-293 K), deformation rates $\left(10^{-5}-10^{-3} \mathrm{~s}^{-1}\right)$ and film thicknesses $(25,75$ and $125 \mu \mathrm{m})$ were investigated. It is discovered, that the forced-elastic state remains for all films up to $4.2 \mathrm{~K}$ of all strain rates $-\sigma$ fors $<\sigma_{\text {r. }}$ In this case, the reserve of elasticity significantly depends on the thickness of the film with a decrease in temperature. A sharp decrease in $\varepsilon_{\mathrm{r}}$ occurs in films: $125 \mu \mathrm{m}$ thick - at $77 \mathrm{~K}, 75 \mu \mathrm{m}$ thick - at $4.2 \mathrm{~K}$. Two variants of deformation curves are possible in a $25 \mu \mathrm{m}$ thick film at $4.2 \mathrm{~K}$ : with a short nonlinear stage or with a long one proceeding jumpily. The working surface of the samples that have undergone jump deformation is covered with a deformation relief, partially representing a delayed highly elastic deformation. The $\sigma_{\text {fors }}$ limit is most sensitive to the strain rate. The nature of the strain rate sensitivity $\sigma_{\text {fors }}(\dot{\varepsilon})$ depends on the temperature and film thickness. The change to the opposite in the character of $\sigma_{\text {fors }}(\dot{\varepsilon})$ and $\sigma_{\mathrm{r}}(\dot{\varepsilon})$ with a decrease in temperature to $4.2 \mathrm{~K}$ in 75 and 125 thick films was found for a first time. Change in the character of бfors $(\dot{\varepsilon})$ is not observed in $25 \mu \mathrm{m}$ thick film which retains the maximum reserve of elasticity at $4.2 \mathrm{~K}$.
\end{abstract}

KEYWORDS: polyimides, low temperatures, limit of forced elasticity, rupture stress, deformation

The study of the mechanical and structural properties of polyimides has been going on for decades, and the results of these studies in the field of normal and elevated temperatures are given in numerous articles, monographs and reference books. Since the end of the XX century, the widespread use of polymers of this class in cryogenics, astronautics and nuclear power began. Interest in the study of their properties has shifted to the area of low temperatures and the effect of radiation factors. It is known that most polymers, including polyimides, become embrittled below room temperature and, especially, the temperature of liquid nitrogen $(77 \mathrm{~K})[1,2]$. Only polypyromellitimide films (such as kapton $\mathrm{H}$ and PM) retain some deformability up to the temperature of liquid helium $(4.2 \mathrm{~K})[3,4]$ and are used (as thermal control coatings and screen-vacuum thermal insulation) in devices operating under extreme conditions. The films of this type are up to $\sim 100 \mu \mathrm{m}$ thick are most widely used.

The compliance of their mechanical properties with the required performance characteristics is one of the criteria for their applicability. These are, first of all, strength and deformability at different strain rates in a wide temperature range of 4.2-300 K. It is important to establish how the film thickness affects these characteristics at helium temperatures, where the elasticity of the films decreases. Another important aspect, already from the point of view of the physics of polymers, is the study of their ability to create a highly oriented structure at low temperatures, the establishment of the physical mechanisms of film shape change under these conditions, since these questions are still open.

In this work, we continued the study of the mechanical properties of polyimide films of the kapton $\mathrm{H}$ type, begun in [5], in wider ranges: temperatures $(4.2-293 \mathrm{~K})$, strain rates $\left(10^{-5}-10^{-3} \mathrm{~s}^{-1}\right)$ and film thicknesses (25-125 microns).

\section{MATERIAL AND METHOD OF RESEARCH}

The objects of study were samples of thermoplastic film of aromatic polyimide - poly-4,4'-diphenylene oxide pyromellitimide, manufactured by PRC (People's Republic of China). Polyimide films kapton H (manufactured in the USA) and PM (manufactured in the Russian Federation) are their well-studied analogs. The thickness of the films was $\delta=25,75$, and $125 \mu \mathrm{m}$.

The structure of films with a thickness of 75 and $125 \mu \mathrm{m}$ in the initial state and after deformation to rupture at 293 and $77 \mathrm{~K}$ was previously investigated in [6] by X-ray diffraction analysis for reflection from the sample plane. Both films were found to be in an amorphous state upon delivery. A higher degree of ordering and a noticeable unevenness in the distribution of the density of the substance over the thickness was found in the initial film with a thickness of $125 \mu \mathrm{m}$. The change in the degree of ordering was observed only in a film with a thickness of $125 \mu \mathrm{m}$ after deformation to rupture (i.e., into the stage of irreversible deformations). The formation of regions with long-range order occurred in it both after deformation at $293 \mathrm{~K}$ and at $77 \mathrm{~K}$, which is in good agreement with the results of [7].Although in the film with $\delta=75 \mu \mathrm{m}$, the contribution of irreversible deformation at $293 \mathrm{~K}$ was greater than in the film with $\delta=125 \mu \mathrm{m}$. 
The structure of a film with $25 \mu \mathrm{m}$ thickness has not been studied. However, films with this type of monomer of small thickness $(<70 \mu \mathrm{m})$, as a rule, are amorphous, according to the data which obtained by other authors in [1,7-9].

Two-blade samples according to State Standard 11262 (Fig. 1) with the tension axis along the direction of the film drawing were using a special die. The sample was fixed in testing machine with special clamping grippers, which gripped and pressed rollers with blades of non-working surfaces of the sample wrapped around them.

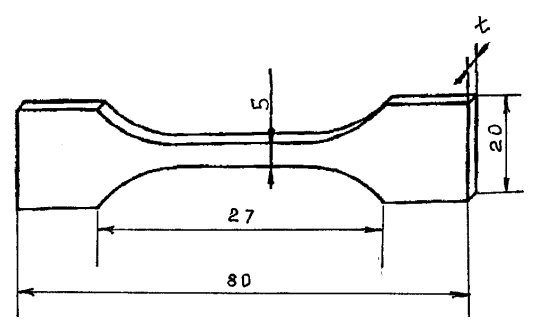

Figure. 1. The shape of the tensile test sample.

The samples deformation under uniaxial tension was performed using FPZ-100/1 tensile testing machine with a low-temperature unit, designed and created in the Institute for Low Temperature Physics and Engineering [10]. Film samples with a thickness of $25 \mu \mathrm{m}$ were tested at three temperatures of 293, 77 and $4.2 \mathrm{~K}$ and three active rod moving speed $\mathrm{V}_{\text {def. }}=$ 0,$085 ; 0,85$ and $7,6 \mathrm{~mm} / \mathrm{min}$, and, correspondingly, with the strain rate $\dot{\varepsilon}=7 \cdot 10^{-5}, 7 \cdot 10^{-4}$ and $6 \cdot 10^{-3} \mathrm{~s}^{-1}$ ( $\dot{\varepsilon}=\mathrm{V}_{\text {def }} / \mathrm{L}_{\mathrm{o}}$, where $\mathrm{L}_{\mathrm{o}}$ is the initial working length of the sample). Film samples of 75 and $125 \mu \mathrm{m}$ were tested at three temperatures with deformation rate $\dot{\varepsilon}=7 \cdot 10^{-5} \mathrm{~s}^{-1}$ and with all rate $\dot{\varepsilon}$ at $\mathrm{T}=4,2 \mathrm{~K}$. Data of investigations for films with a thickness of 75 and 125 microns with strain rates $\dot{\varepsilon}$ $=7 \cdot 10^{-4}$ and $6 \cdot 10^{-3} \mathrm{~s}^{-1}$ at 293 and $77 \mathrm{~K}$ were received earlier [5].

In the process of deformation a tensile diagram was recorded in the coordinates "load P-elongation $\Delta \mathrm{L}$ ", from which the following mechanical characteristics were determined: the apparent limit of forced elasticity, corresponding to the stress, at which the highly elastic deformation is $1 \%$ (according to State Standard 14236 ), $\sigma_{\text {forc. }}=\mathrm{P}_{1 \%} / \mathrm{S}_{\mathrm{o}}$; rupture stress of the sample $\sigma_{\mathrm{r}}=\mathrm{P}_{\mathrm{r}} / \mathrm{S}_{\mathrm{o}}$, where $\mathrm{S}_{\mathrm{o}}$ is the initial cross section of the sample; relative deformation to rupture $\varepsilon_{\mathrm{r}}=\Delta \mathrm{L}_{\mathrm{r}} / \mathrm{L}_{\mathrm{o}}$, where $\Delta \mathrm{L}_{\mathrm{r}}$ elongation corresponding to the moment of the sample rupture, and $\mathrm{L}_{\mathrm{o}}-$ value of the original working length of the sample.

Elongation to rupture $\Delta \mathrm{L}_{\mathrm{r}}$ can include same contributions: reversible (elastic) elongation $\Delta \mathrm{L}_{\text {elast}}$, associated with the unrelaxed elastic modulus of the polymer, elongation $\Delta \mathrm{L}_{\text {high el.1, }}$, due to highly elastic deformation reversible at the test temperature, elongation $\Delta \mathrm{L}_{\text {high el.2, }}$, due to delayed high elastic deformation, and elongation $\Delta \mathrm{L}_{\text {irrevers, }}$ corresponding to irreversible deformation that does not disappear upon heating up to the melting temperature $\mathrm{T}_{\mathrm{m}}$. The types of contributions may vary depending on the test temperature. The procedure for their determination is described in detail in [5]. In this work, we do not give the values of the contributions, but, the deformed to rupture films were annealed at $623 \mathrm{~K}\left(350^{\circ} \mathrm{C}\right)$ for 2 hours in air as in [5], to determine the presence of the contribution of irreversible deformation and the total value of highly elastic deformation $\left(\varepsilon_{\text {high el.1 }}+\varepsilon_{\text {high el.2 }}\right)$.

Before the low-temperature test, the sample in the deforming device was held in a cryostat with a refrigerant for at least $30 \mathrm{~min}$.

All mechanical characteristics are presented below as average values based on the results of tests of 4 - 10 samples, depending on the magnitude of the spread of values under the given test conditions.

Fractures of the samples were studied using an optical microscope МБС-9.

\section{RESULTS OF EXPERIMENTS}

Deformation curves. Fig. 2 a,b shows typical curves "stress $(\sigma)$-deformation $(\varepsilon)$ " of polyimide film samples of different thickness at temperatures 293, 77 and 4,2 $\mathrm{K}$ for the limiting deformation rates in this experiment $-7 \cdot 10^{-5} \mathrm{~s}^{-1}$ (Fig. 2a) and $6 \cdot 10^{-3} \mathrm{~s}^{-1}$ (Fig. 2b). It can be seen that, the tension diagrams for films with a thickness of 75 and $125 \mu \mathrm{m}$ at all temperatures exhibit two stages: a linear stage associated with elastic deformation and a nonlinear stage including the contributions of highly elastic deformation (reversible with removal of the load and delayed) and at $293 \mathrm{~K}$ containing the contribution of irreversible deformation [5]. The first elastic linear stage occupies most of the deformation curves of samples of these films at temperature of $4.2 \mathrm{~K}$. In this case, a stress jump is observed at a short nonlinear stage on the curves of some samples of films with a thickness of $75 \mu \mathrm{m}$ at all deformation rates.

Curves $(\sigma-\varepsilon)$ of films of $25 \mu \mathrm{m}$ at temperatures of 293 and $77 \mathrm{~K}$ have three stages: linear elastic and two nonlinear. The slope coefficient $d \sigma / d \varepsilon$ is higher in the last third stage than in the second nonlinear stage. Samples of a thin film at $4.2 \mathrm{~K}$ at all test rates exhibit two different types of deformation curves: 1) 2-stage curves $(\sigma-\varepsilon)$ similar to the other two films with a very short second nonlinear stage, monotonic or containing one or two jump of stress (Fig. 2, curves 1a), 2) curves with a noticeable (up to $\varepsilon \sim 35 \%$ ) nonlinear stage of deformation proceeding jumpily (Fig. 2, curves $1 \mathrm{~b}$ ). Curves $(\sigma-\varepsilon)$ are three-stage at the lowest strain rate $\dot{\varepsilon}=7 \cdot 10^{-5} \mathrm{~s}^{-1}$ - the nonlinear range has two stages with different slope coefficients, as at higher temperatures.

Temperature influence on mechanical properties. Figure 3 shows the temperature dependences of the average values of mechanical characteristics: the limit of forced elasticity $\sigma_{\text {forc }}$ (Fig. 3a, d), rupture stress $\sigma_{\mathrm{r}}$ (Fig. 3b, e) and relative deformation before rupture $\varepsilon_{\mathrm{r}}$ (Fig. 3c, f) of films of different thicknesses at two limiting strain rates, $\dot{\varepsilon}=7 \cdot 10^{-5} \mathrm{~s}^{-1}$ (Fig. 3 a,b,c) and $\dot{\varepsilon}=6 \cdot 10^{-3} \mathrm{~s}^{-1}$ (Fig. 3 e,f,g). 


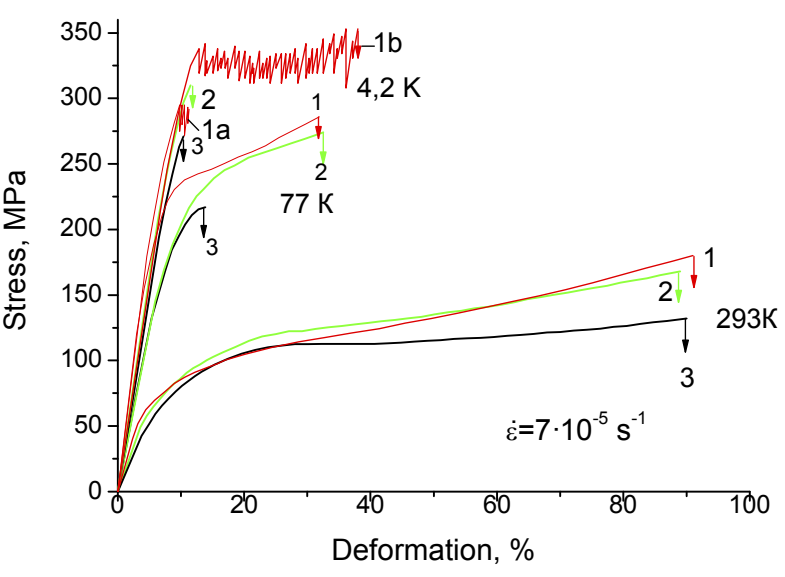

a

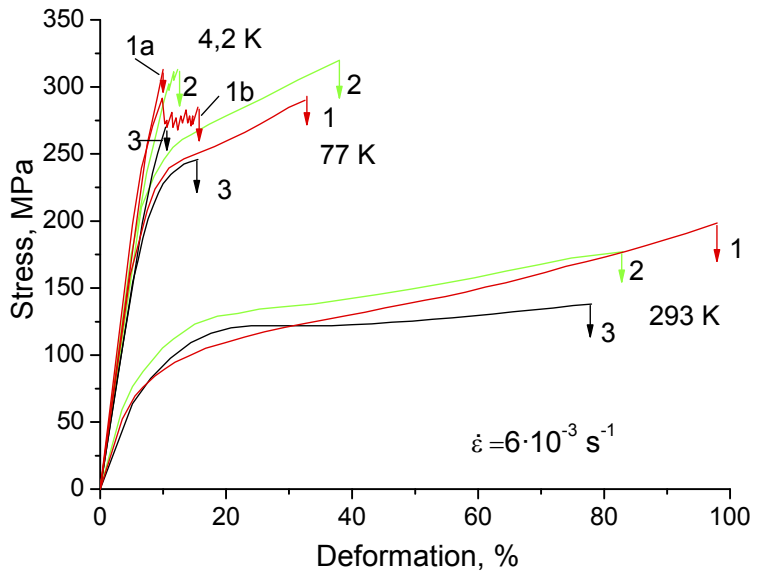

$\mathrm{b}$

Figure. 2. The typical deformation curves of films of $25 \mu \mathrm{m}$ (curves $1,1 \mathrm{a}, \mathrm{b}$ ), $75 \mu \mathrm{m}$ (curves 2 ) and $125 \mu \mathrm{m}$ (curves 3 ) at interval temperatures $4,2-293 \mathrm{~K}$ and deformation rates: a) $-\dot{\varepsilon}=7 \cdot 10^{-5} \mathrm{~s}^{-1}$, б) $-\dot{\varepsilon}=6 \cdot 10^{-3} \mathrm{~s}^{-1}$

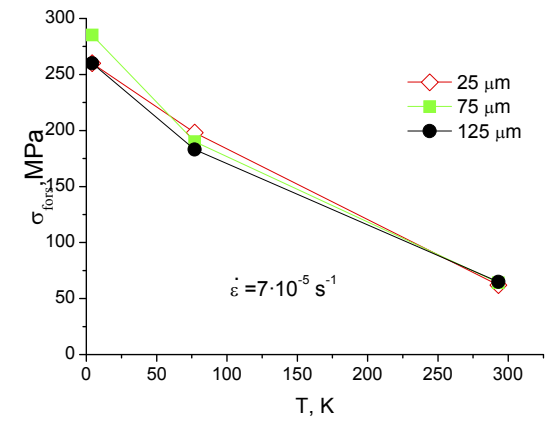

a

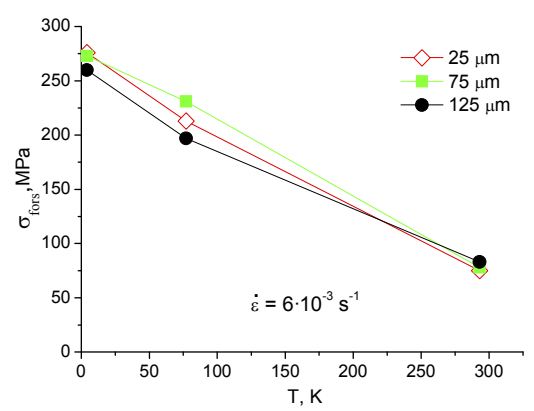

d

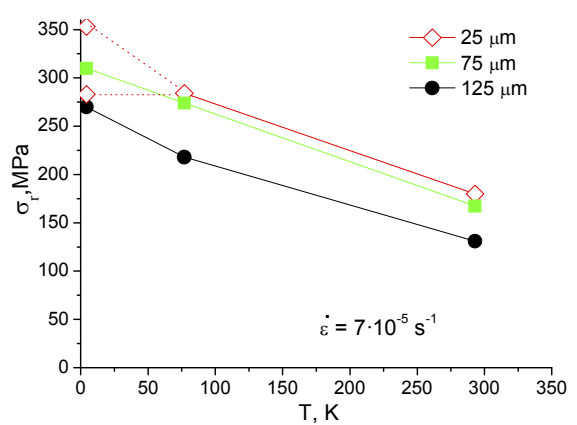

b

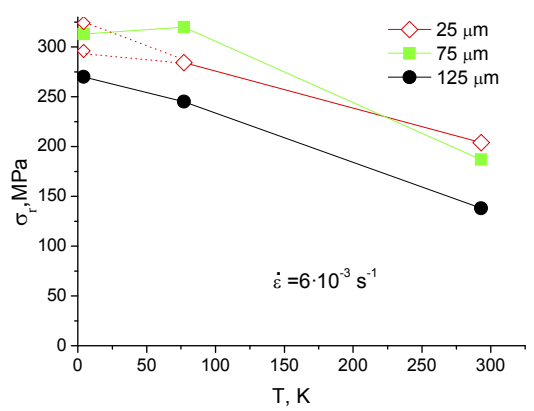

$\mathrm{e}$

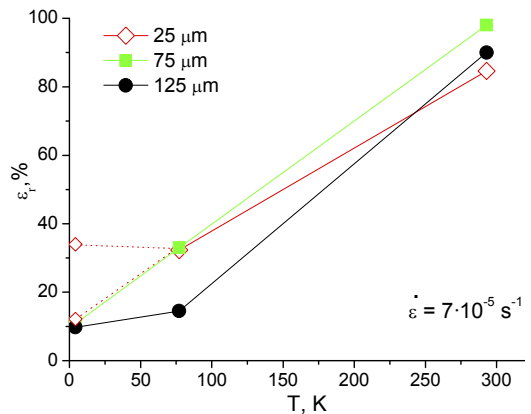

$\mathrm{c}$

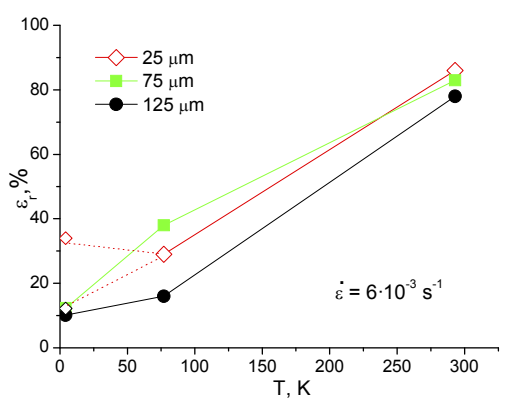

f

Figure. 3. Temperature dependences of the mechanical characteristics of polyimide films in the temperature range $4,2-293 \mathrm{~K}$ at strain rates $\dot{\varepsilon}=7 \cdot 10^{-5} \mathrm{~s}^{-1}$ (a,b,c) and $\dot{\varepsilon}=6 \cdot 10^{-3} \mathrm{~s}^{-1}$ (d,e,f): a, d - forced elasticity limit, b,e- rupture stress; c,f - relative deformation to rupture

Figure 4 shows the limits of the scatter of the values of mechanical characteristics $\pm\left(\Delta \sigma_{\text {forc }} / \sigma_{\text {forc }}, \%, \Delta \sigma_{\mathrm{r}} / \sigma_{\mathrm{r}}, \%\right.$ and $\left.\Delta \varepsilon_{\mathrm{r}} / \varepsilon_{\mathrm{r}}, \%\right)$ under these conditions. The scatter of the measured characteristics in films of 75 and $125 \mu \mathrm{m}$ is significantly lower than in a film of $25 \mu \mathrm{m}$, and changes with decreasing temperature are also much less. The spread in the values of the characteristics of a $25 \mu \mathrm{m}$ film sharply increases with decreasing temperature, especially for the values of deformation to rupture $\varepsilon_{\mathrm{r}}$. As shown in Fig. 2, for samples of a film with a thickness of $25 \mu \mathrm{m}$ at $4.2 \mathrm{~K}$, two types of curves are observed, and for $\varepsilon_{\mathrm{r}}$ it is possible to distinguish, as it were, two average values and two values of the scatter (Fig. 4c, d) for each type of curves. For rupture stress, two predominant average values can also be distinguished, but in this case there is no clear correspondence - higher strength values and higher deformation, or vice versa. Although at a strain rate of $\dot{\varepsilon}=7 \cdot 10^{-5} \mathrm{~s}^{-1}$ the samples which show curves of type $1 \mathrm{~b}$ (Fig. $2, \mathrm{~T}=4.2 \mathrm{~K}$ ) have predominantly higher 
values, and at $\dot{\varepsilon}=6 \cdot 10^{-3} \mathrm{~s}^{-1}$ - lower. In this regard, two limiting values are shown in Fig. 3 for the rupture stress and relative deformation to rupture of the $25 \mu \mathrm{m}$ film at $4.2 \mathrm{~K}$ instead of the average values of the characteristics.

Figure 3 shows, that the values of the forced elasticity limit $\sigma_{\text {fors. }}$ of the films strongly depend on temperature and only slightly depend on the thickness. The limit $\sigma_{\text {fors. }}$ with decreasing temperature from room temperature to $4.2 \mathrm{~K}$ increases in films of all thicknesses by more than 4 times at a minimum strain rate of $7 \cdot 10^{-5} \mathrm{~s}^{-1}$ and by $3.2-3.4$ times at a maximum rate of $6 \cdot 10^{-3} \mathrm{~s}^{-1}$. The magnitude of the rupture stress $\sigma_{\mathrm{fr}}$ in all films with a decrease in temperature to $4.2 \mathrm{~K}$ grows much more slowly - by 1.7-2 times. Even at $4.2 \mathrm{~K}$, at all deformation rates, there is a certain reserve of elasticity - the ratio $\sigma_{\text {fors }} / \sigma_{\mathrm{r}}<1$ and is equal to $\sim 0.94,0.9$ and 0.8 , respectively, for films with $\delta=125,75$ and $25 \mu \mathrm{m}$. The rupture stress $\sigma_{\mathrm{r}}$ depends on the film thickness much more strongly than the limit $\sigma_{\text {fors. }}$. Thus, a thick film $(\delta=125 \mu \mathrm{m})$ has the lowest values $\sigma_{\text {r. }}\left(20-30 \%\right.$ lower than the values $\sigma_{\mathrm{r}}$ of the average film) in the entire temperature range at all strain rates. The magnitude $\sigma_{\mathrm{r}}$ of the films $75 \mu \mathrm{m}$ and $25 \mu \mathrm{m}$ differ significantly less. The maximum difference is observed at low temperatures and reaches $10-17 \%$, and depending on the strain rate, either the values $\sigma_{\mathrm{r}}$ of the thinnest film $\left(\dot{\varepsilon}=7 \cdot 10^{-5} \mathrm{~s}^{-1}\right)$ or the average $\left(\dot{\varepsilon}=6 \cdot 10^{-3} \mathrm{~s}^{-1}\right)$ are higher, which is associated, as will be shown below, with the different strain rate sensitivities of the films of these thicknesses.

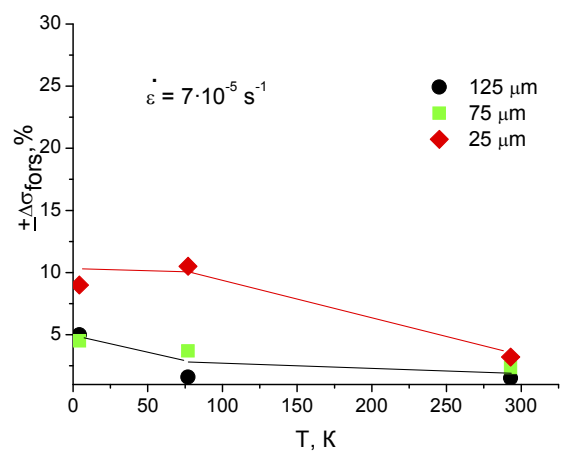

a

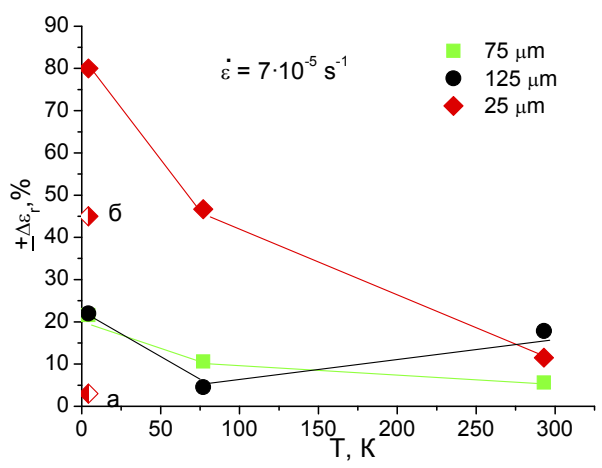

c

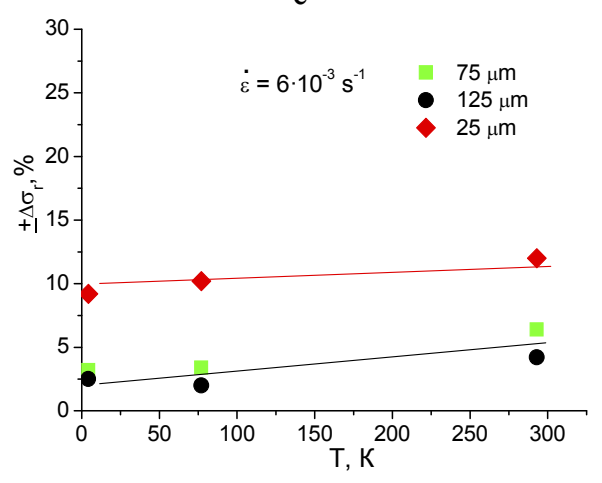

e

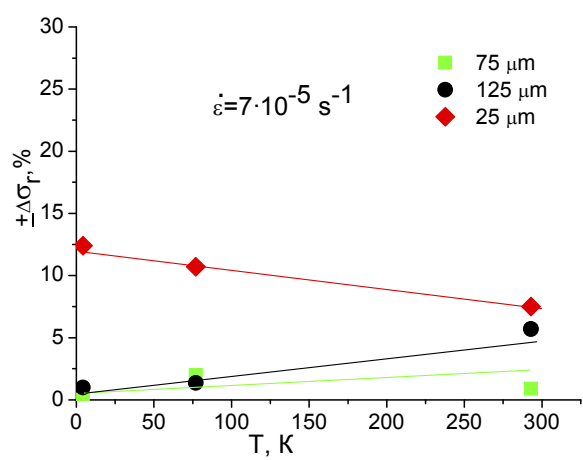

$\mathrm{b}$

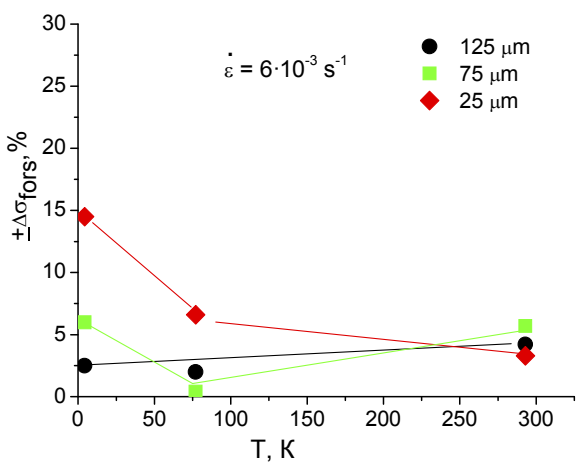

d

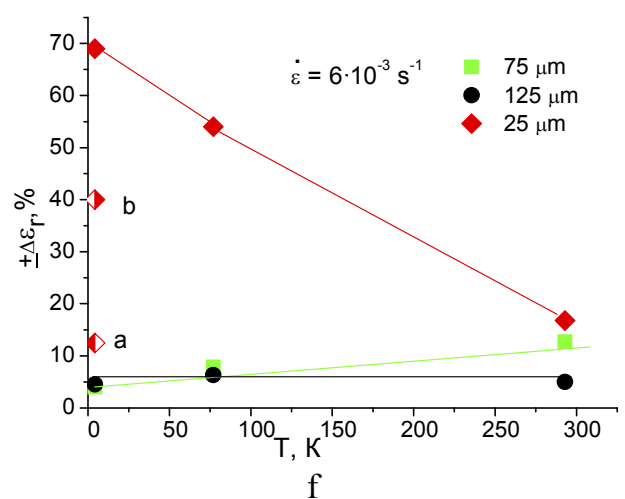

Figure. 4. Temperature dependences of the spread in the values of the mechanical characteristics of polyimide films in the temperature range $4,2-293 \mathrm{~K}$ at strain rates $\dot{\varepsilon}=7 \cdot 10^{-5} \mathrm{~s}^{-1}$ (a,b,c) and $\dot{\varepsilon}=6 \cdot 10^{-3} \mathrm{~s}^{-1}$ (d,e,f): a, d - error in measuring forced elasticity limit, b,e- rupture stress; c,f - relative deformation to rupture (points a and b correspond to the values $+\Delta \varepsilon_{\mathrm{r}} / \varepsilon_{\mathrm{r}}$ for curves of type $\mathrm{a}$ and $\mathrm{b}$ for samples of a film with a thickness of $25 \mu \mathrm{m}$ at $4.2 \mathrm{~K}$ in Fig. 2)

The temperature dependences of the deformation before rupture (Fig. $3 \mathrm{c}, \mathrm{f}$ ) indicate that a film with a thickness of $125 \mu \mathrm{m}$ sharply decreases its elasticity already in the range of $\mathrm{T}=77 \mathrm{~K}$, and a film of $75 \mu \mathrm{m}$ - in the range of $4.2 \mathrm{~K}$. 
However, the level of highly elastic deformation even in a film $125 \mu \mathrm{m}$ at $4.2 \mathrm{~K}$ remains at a level of not less than $2.5 \%$ at all strain rates. In the thinnest film of $25 \mu \mathrm{m}$ at $4.2 \mathrm{~K}$, the samples have two average values: the values $\varepsilon_{\mathrm{r}}$ : magnitudes $\varepsilon_{\mathrm{r}}$ of some of the samples practically coincide with the values $\varepsilon_{\mathrm{r}}$ of thick films, and some of the samples demonstrate elasticity, as at $77 \mathrm{~K}$.

Strain rate influence. The dependences of the average values of the mechanical characteristics of the films on the strain rate at temperatures of 293, 77, and $4.2 \mathrm{~K}$ are shown in Fig.5a-c.
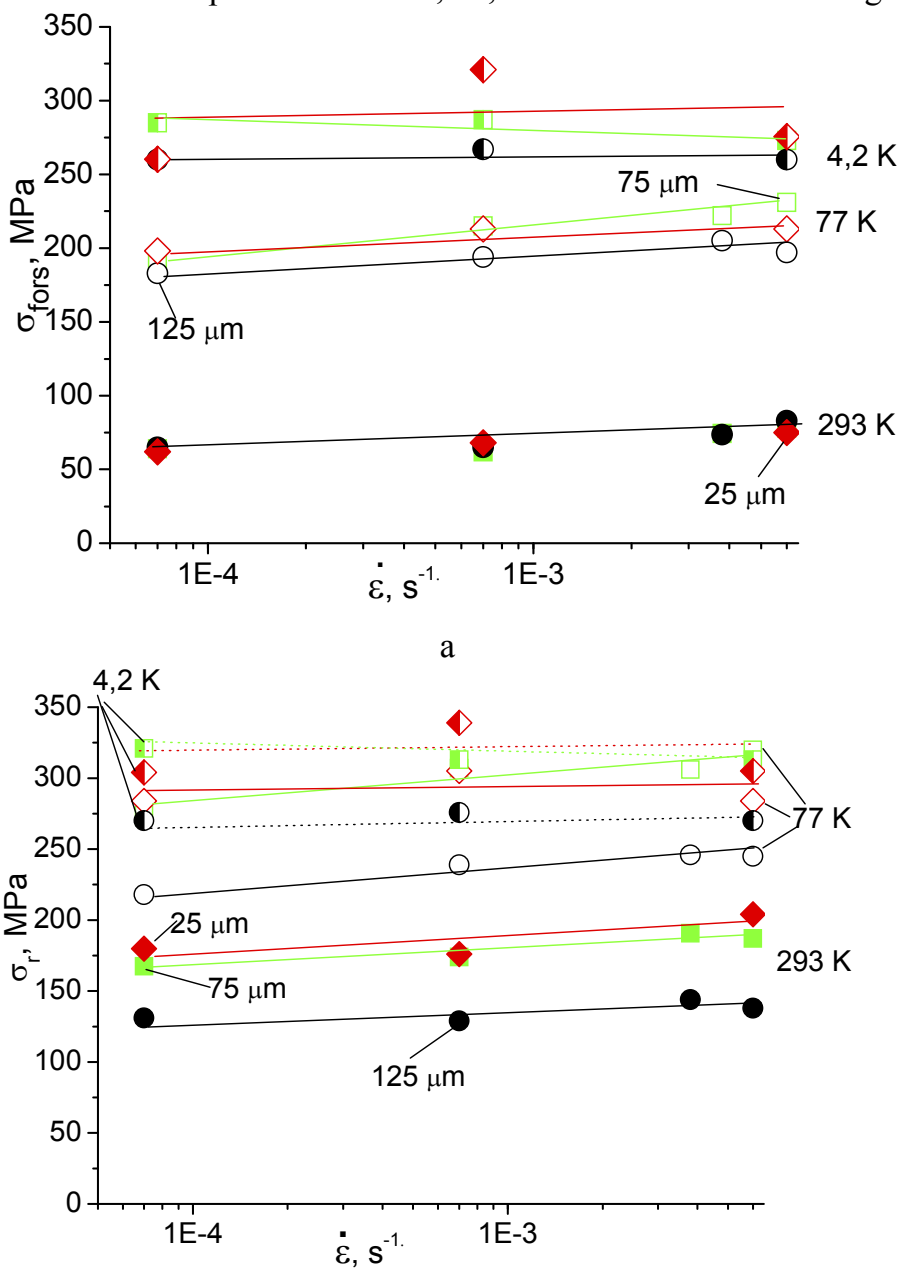

Let us consider the dependence of the forced elasticity limit of films on the strain rate $\sigma_{\text {fors. }}(\dot{\varepsilon})$. Fig. 5a shows that at room temperature the values $\sigma_{\text {fors }}$ of all films practically coincide in the entire range of strain rates and grow weakly with increasing $\dot{\varepsilon}$, which is in good agreement with the data obtained on polymer films earlier [2]. As noted in [5], limit $\sigma_{\text {fors }}$ in thicker films increases with strain rate $\dot{\varepsilon}$ at $77 \mathrm{~K}$ (especially in a film with $\delta=75 \mu \mathrm{m}$ ). The slope of the dependence $\sigma_{\text {fors. }}(\dot{\varepsilon})$ of the thinnest film remains the same as at $293 \mathrm{~K}$ and, accordingly, the values of limit $\sigma_{\text {fors. }}$ at strain rate $\dot{\varepsilon}=6 \cdot 10^{-3} \mathrm{~s}^{-1}$ are lower than the $\sigma_{\text {fors. }}$ values of the average film thickness.

At $4.2 \mathrm{~K}$, the limit $\sigma_{\text {fors. }}$ of a thinnest film practically ceases to depend on deformation rate $\dot{\varepsilon}$, while for thicker films an inverse relationship is observed - an increase in the limit $\sigma_{\text {fors. }}$ with decreasing rate $\dot{\varepsilon}$. Such a rate dependence $\sigma_{\text {fors. }}(\dot{\varepsilon})$ at $\mathrm{T}=4.2 \mathrm{~K}$ was observed for the first time. Dependencies $\sigma_{\mathrm{r}}(\dot{\varepsilon})$ behave in a similar way (Fig.5b). It should be noted that the values of rupture stress $\sigma_{\mathrm{r}}$ at $4.2 \mathrm{~K}$ for all three films at the highest strain rate of $\dot{\varepsilon}=6 \cdot 10^{-3}$ $\mathrm{s}^{-1}$ are close to those at $77 \mathrm{~K}$. In this regard, in order to better distinguish the dependences of $\sigma_{\text {fr. }}(\dot{\varepsilon})$ at $77 \mathrm{~K}$ and $4,2 \mathrm{~K}$, the latter for clarity in Fig. $5 \mathrm{~b}$ are shown by a dotted line. For the same purpose, the dependences of $\sigma_{\mathrm{r}}(\dot{\varepsilon})$ at $4.2 \mathrm{~K}$ in Fig. $5 \mathrm{c}$ are also represented by dotted lines.

The relative deformation before rupture $\varepsilon_{\mathrm{r}}$

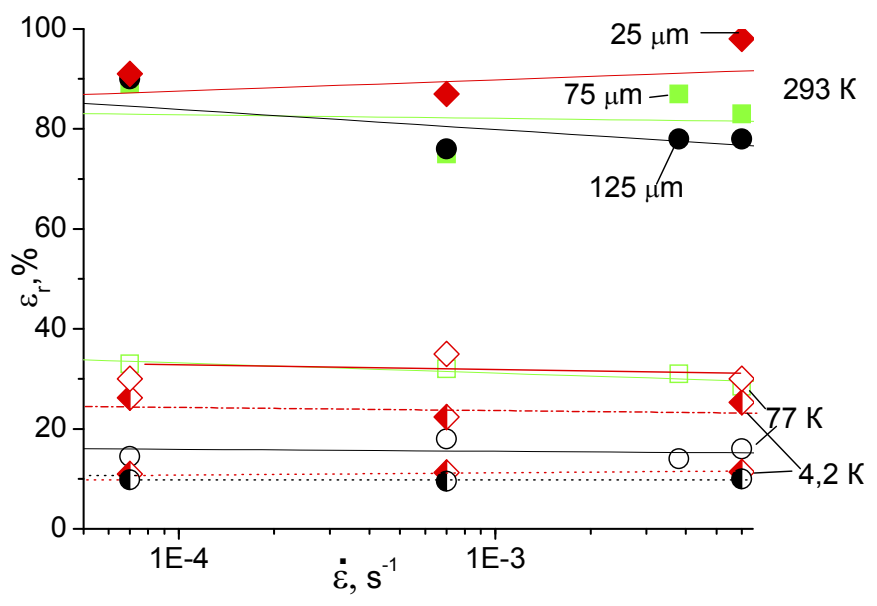

c

Figure 5. Dependences of the forced elasticity limit (a), rupture stress (b) and relative deformation before rupture (c) of polyimide films on the rate at $4.2,77$, and $293 \mathrm{~K}$. for all films (except for the $125 \mu \mathrm{m}$ film at $4.2 \mathrm{~K}$ ), taking into account the large scatter of values, can be considered practically independent of the strain rate at all test temperatures. It should only be noted that the values of $\varepsilon_{\mathrm{r}}$ at temperatures of a sharp decrease in elasticity practically coincide for all films. Namely, for samples of a film with a thickness of $125 \mu \mathrm{m}$, the $\varepsilon_{\mathrm{r}}$ values practically coincide at temperatures of 77 and $4.2 \mathrm{~K}$. At $4.2 \mathrm{~K}$, the $\varepsilon_{\mathrm{r}}$ values coincide for all samples of films with a thickness of 75 and $125 \mu \mathrm{m}$ and samples of a film with $25 \mu \mathrm{m}$, having a deformation curve of the type 1a (Fig. 2). In samples of a thinnest film with deformation curves of type $1 \mathrm{~b}$ (Fig. 2), the $\varepsilon_{\mathrm{r}}$ values at $4.2 \mathrm{~K}$ at all strain rates are close to those at $77 \mathrm{~K}$.

Fracture of films. In fig. 6 (a-i) and 7 (a-i) show photographs of the fracture zones of 
samples of different thicknesses, deformed at temperatures of investigation and limiting deformation rates. Figures $6 \mathrm{i}$ and $7 \mathrm{i}$ show the fracture zones of film samples with a thickness of $25 \mu \mathrm{m}$, which at $4.2 \mathrm{~K}$ had the character of curves $(\sigma$ $-\varepsilon$ ), similar to that of thicker films (type 1a, Fig. 2).Figures 8a-d show the surface relief of thin film specimens, which found noticeable jump-like deformation at $4.2 \mathrm{~K}$.

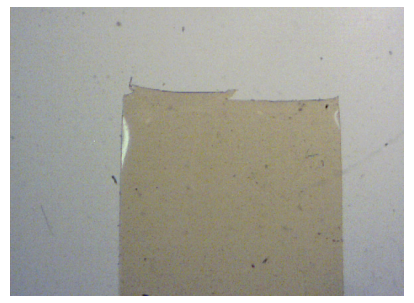

a

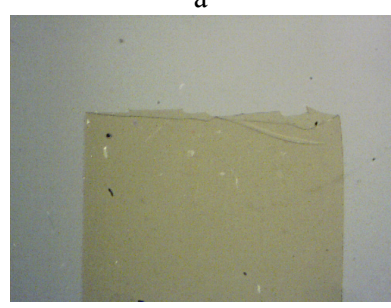

d

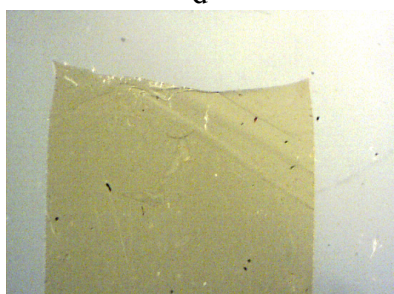

g

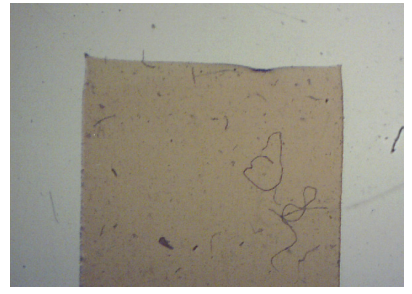

$\mathrm{b}$
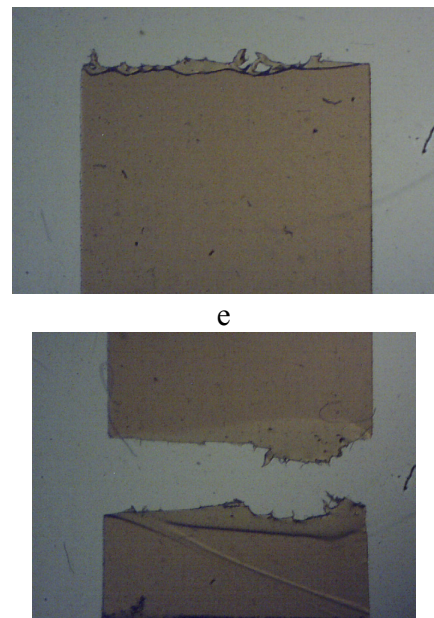

$\mathrm{h}$
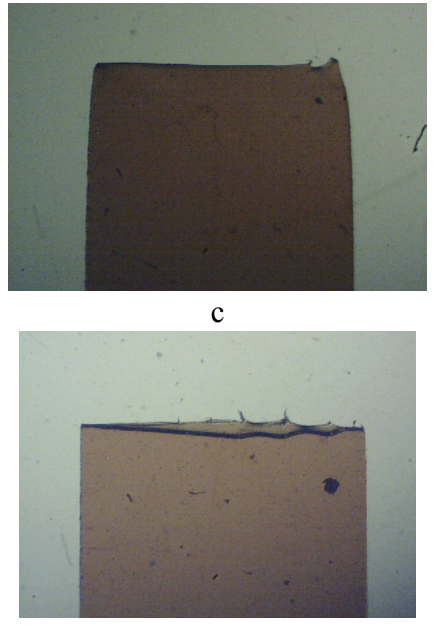

f

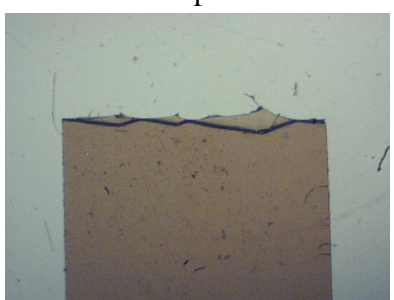

Figure 6. Surfaces of samples with a thickness 25 (a, d, g), $75(\mathrm{~b}, \mathrm{e}, \mathrm{h})$ and $125 \mu \mathrm{m}(\mathrm{c}, \mathrm{f}, \mathrm{i})$ in the fracture zone at temperatures of 293 (a, b.c), 77 (d, e, f) and $4.2 \mathrm{~K}(\mathrm{~g}, \mathrm{~h}, \mathrm{i})$ at a strain rate $\dot{\varepsilon}=7 \cdot 10^{-5} \mathrm{~s}^{-1}$

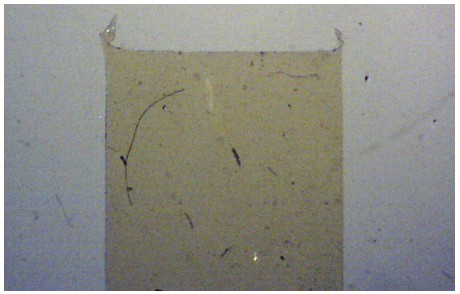

a

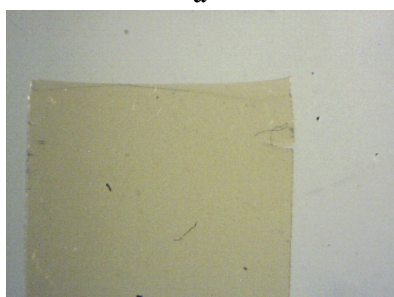

d

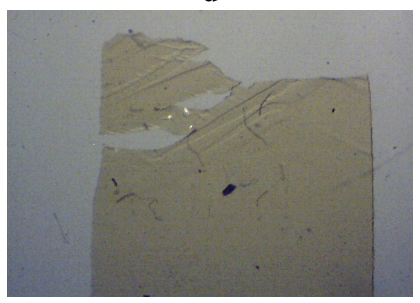

g

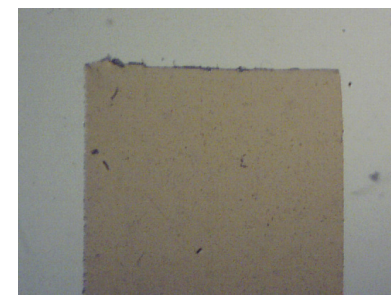

b

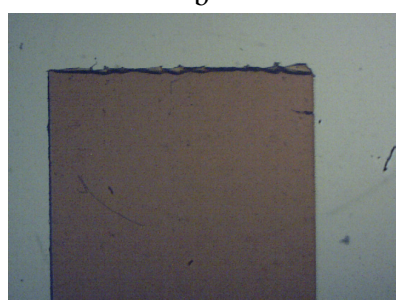

e

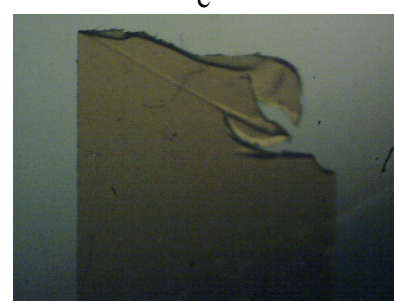

$\mathrm{h}$
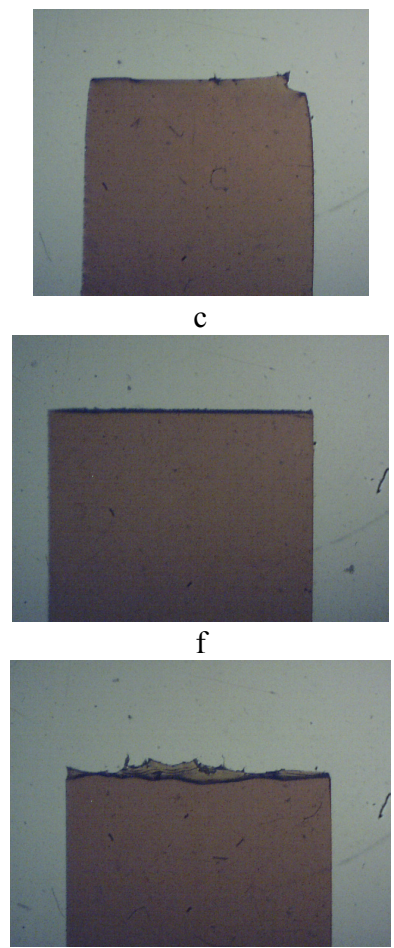

Figure 7. Surfaces of samples with a thickness 25 (a, d, g), $75(\mathrm{~b}, \mathrm{e}, \mathrm{h})$ and $125 \mu \mathrm{m}(\mathrm{c}, \mathrm{f}, \mathrm{i})$ in the fracture zone at temperatures of 293 (a, b.c), 77 (d, e, f) and $4.2 \mathrm{~K}(\mathrm{~g}, \mathrm{~h}, \mathrm{i})$ at a strain rate $\dot{\varepsilon}=6 \cdot 10^{-3} \mathrm{~s}^{-1}$ 
Figures 6 and 7 show that the fracture of the films occurs by tearing off perpendicular to the tensile axis of the sample at temperatures of 293 and $77 \mathrm{~K}$. Weak necks in the plane of the film, which are absent in thickness, were found on the fractures of all films at room temperature. Up to a temperature of $4.2 \mathrm{~K}$, the neck is retained only in a film with a thickness of $25 \mu \mathrm{m}$. Ties and shear zones parallel to the separation zone (apparently, the tear zones of a part of the fibers) appear in films with a thickness of 75 and $125 \mu \mathrm{m}$ at 77 and $4.2 \mathrm{~K}$. The length of the tension bars extended from the zone of tear at $77 \mathrm{~K}$ decreases with an increase in the strain rate $\dot{\varepsilon}$, especially in a film with a thickness of $125 \mu \mathrm{m}$.

The shape of the $125 \mu \mathrm{m}$ film surface in the fracture zone, which is characteristic at $77 \mathrm{~K}$, remains at the temperature of liquid helium. Shear bands at an angle of $60^{\circ}$ to the tension axis associated with the fracture zone appear in addition to tension bars at a low strain rate in the thinnest film of $25 \mu \mathrm{m}$ at $77 \mathrm{~K}$. At a strain rate of $\dot{\varepsilon}=6 \cdot 10^{-3} \mathrm{~s}^{-1}$, tension bars and shear bands in it are absent and well the neck is visible in the plane of the film.

Shear bands at an angle of $60^{\circ}$ to the tension axis associated with the fracture zone are observed at $4.2 \mathrm{~K}$ in films of small and medium thickness at all strain rates. Cracks appear in them at a high strain rate. Shear bands are observed only near a fracture in films with a thickness of $25 \mu \mathrm{m}$ with a small elongation to rupture. This deformation relief in films of both thicknesses is irreversible and is retained after annealing destroyed samples at $350^{\circ} \mathrm{C}$ for 2 hours. Shear bands, oriented in two directions at an angle of $60^{\circ}$ to the tension axis, extend over the entire working part of the sample in films with a thickness of $25 \mu \mathrm{m}$ with a noticeable nonlinear stage (Fig.8a and b). The number of shear bands agrees well with the number of jumps on the deformation curves. Part of this relief disappears after annealing the destroyed samples at $350^{\circ} \mathrm{C}$ for 2 hours. (Fig.8c and d).

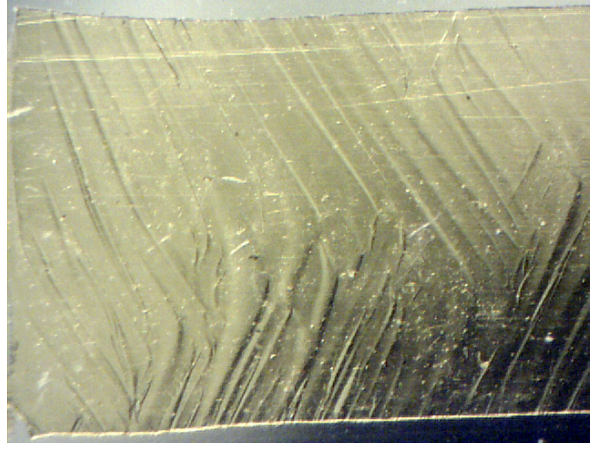

a

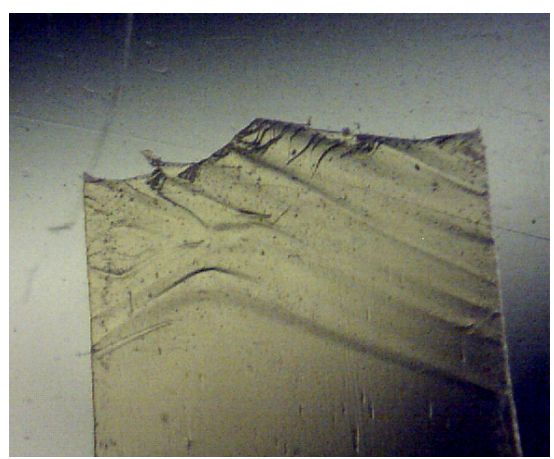

$\mathrm{c}$

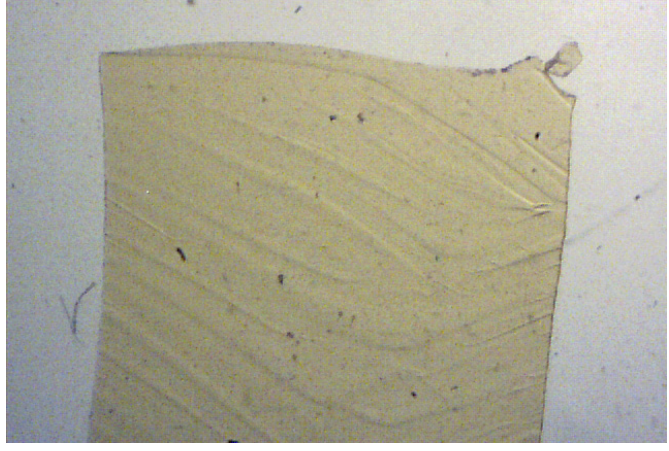

$\mathrm{b}$

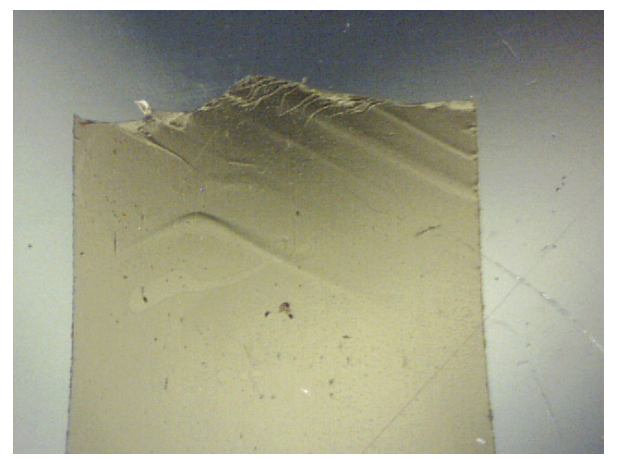

d

Figure 8. Surfaces of the working part of $25 \mu \mathrm{m}$ thick specimens deformed to rupture at $4.2 \mathrm{~K}$ at strain rates $\dot{\varepsilon}: 7 \cdot 10^{-5} \mathrm{~s}^{-1}$ (a, c) and $6 \cdot 10^{-3} \mathrm{~s}^{-1}$ (b) after warming up to room temperature (a-c) and annealing at $350^{\circ} \mathrm{C}$ for 2 hours. (d)

\section{DISCUSSION OF INVESTIGATION RESULTS}

The deformation curves of the studied amorphous films do not show a maximum upon transition to the forced elastic state, while the films have high limits of forced elasticity and strength. This is typical for pre-stretched, oriented amorphous polymers [2]. The X-ray method can detect such a texture only when shooting at the end of the film, perpendicular to the axis of the broach in the technological process. According to the available data of X-ray diffraction analysis [6], obtained during recording by reflection from the film plane, it was found that the initial films have different degrees of ordering and density. In the case of linear polymer molecules, this may mean that the polymer chains have different angles of disorientation along the tensile axis in films of different thicknesses. A film with a thickness of $125 \mu \mathrm{m}$ has the highest ordering in the initial state. Long-range order is formed in it after deformation at both $293 \mathrm{~K}$ and $77 \mathrm{~K}$.

Despite the larger contribution of irreversible deformation, long-range order was not detected in the thinner film $(75 \mu \mathrm{m})$. However, the ordering processes in this and even more disoriented film with a thickness of 25 are seemed to 
proceed more intensively. The appearance on the deformation curves of a $25-\mu \mathrm{m}$-thick film of the second nonlinear stage with a higher hardening coefficient, which is observed in some samples even at $4.2 \mathrm{~K}$, indicates this. This allows us to assume the possibility of orientation in this film under the action of an external force not only of individual segments of molecules, but also the orientation of molecules as a whole and even bundles of molecules along the tensile direction at the second nonlinear stage. But these processes are also more reversible when unloading due to the smaller thickness. In films deformed at low temperatures, these processes are also reversible upon heating to room temperature.

Irreversible deformation that develops at the last stages of deformation is associated not only with shear deformation without violating the integrity (orientation), but also with the processes of material destruction - the formation of microcavities, microcracks and their growth in the oriented material. This is especially evident at low temperatures, where deformation begins to proceed partially localized already at $77 \mathrm{~K}$ and completely at $4.2 \mathrm{~K}$. The appearance at $77 \mathrm{~K}$ of a relief in the form of shear bands observed on the surfaces of deformed samples of the thinnest film $(25 \mu \mathrm{m})$ near the fracture, and in thicker films - directly in the fracture zone indicates this. Cracks are also clearly visible on the surface of shear bands at $4.2 \mathrm{~K}$. The retention of shear bands after annealing in films deformed at $77 \mathrm{~K}$ and the formation of cracks in them at $4.2 \mathrm{~K}$ indicates that the main process of the formation of localization zones is precisely the processes of destruction - the formation of microdefects and the development of microcracks, which become macroscopic at $4.2 \mathrm{~K}$.

Despite the significant reduction in elasticity and the appearance of cracks in the shear bands from the point of view of the ratio of the values of the forced elasticity limit and the rupture stress $\left(\sigma_{\text {fors }}<\sigma_{\mathrm{r}}\right)$ at these strain rates, the brittleness temperature $T_{b r}$ is not yet reached in any of the films even at $4.2 \mathrm{~K}$. However, the appearance of strain rate sensitivities $\varepsilon_{\mathrm{r}}(\dot{\varepsilon})$ in films with a thickness of 75 and $125 \mu \mathrm{m}$ at $4.2 \mathrm{~K}$ with a slope opposite to that at $77 \mathrm{~K}$ indicates that the achievement of $\mathrm{T}_{\text {br }}$ is possible at higher strain rates. Although there is a weak margin of orientational elasticity in these films at $4.2 \mathrm{~K}$, the main process occurring at the nonlinear stage of deformation is the formation and growth of microcracks according to the microstructures of fractures.

The ability to orient the segments of polymer molecules without cracking in the places of localization of deformation is retained in a film $25 \mu \mathrm{m}$ thick at $4.2 \mathrm{~K}$. This is evidenced by the disappearance of a part of the relief during subsequent annealing (Fig.8c, d), the presence of a neck in the fracture zone (Fig. $6 \mathrm{~g}$ and $7 \mathrm{~g}$ ) and the smallest ratio $\sigma_{\text {fors }} / \sigma_{\mathrm{r}}$. However, the competition between the course of orientation processes without and with the formation of cracks is strong. As a result, some specimens with a more favorable arrangement of molecular chains exhibit high elasticity values, while in others, cracking immediately develops with destruction of the specimen.

The limit $\sigma_{\text {fors }}$ determines the stress at which the forced elastic deformation begins to develop steadily, i.e. processes of rearrangement of segments of polymer molecules occur. When the external force changes, they lag behind the equilibrium ones, i.e. have a relaxing nature. According to the developed relaxation theory, $\sigma_{\text {fors }}$ depends on the deformation rate of the material and increases with an increase in the latter, which was observed in various polymers [2] and by us at 293 and $77 \mathrm{~K}$. A change in the film thickness and a change in the structure, which are observed with a change in the thickness of the initial films, in the room temperature area does not lead to a change in the slope of the $\sigma_{\text {fors }}(\dot{\varepsilon})$ dependence for films of different thicknesses, or to a change in the $\sigma_{\text {fors }}$ values.

The difference in the thickness and in the initial degree of ordering of the structure of the films leads with a decrease in temperature to $77 \mathrm{~K}$ to different values of the slopes of the dependences $\sigma_{\text {fors }}(\dot{\varepsilon})$. However, an increase in $\sigma_{\text {fors }}$ with an increase in $\dot{\varepsilon}$ occurs for all films. It can be assumed that microfracture processes begin to operate at all deformation rates simultaneously with entropic orientational processes in a film with $\delta=125 \mu \mathrm{m}$, which sharply decreases its elasticity already at $77 \mathrm{~K}$. As a result, no significant growth of $\sigma_{\text {fors }}$ occurs with increasing speed. The processes of orientation of segments of polymer molecules continue to remain primary in the film with $\delta=75 \mu \mathrm{m}$ at all strain rates. The critical relaxation time $\tau$ (the onset of the development of highly elastic deformation) can be achieved at a lower temperature with an increase in the strain rate at significantly higher stresses $\sigma_{\text {fors. }}$. And the processes of orientation in a film with $\delta=25 \mu \mathrm{m}$, which has the lowest density and the most amorphous structure, are the least complicated and the slope of the $\sigma_{\text {fors }}(\dot{\varepsilon})$ dependence is similar to that at $\mathrm{T}=293 \mathrm{~K}$.

The processes of orientation of both molecular segments and microfracture seem to turn on almost simultaneously when the $\sigma_{\text {fors }}$ limit is reached at $4.2 \mathrm{~K}$ in thicker films $(75$ and $125 \mu \mathrm{m})$. Moreover, the higher the rate of deformation, the earlier the processes of microfracture start. As a result, the dependences $\sigma_{\text {fors }}(\dot{\varepsilon})$ and $\sigma_{\mathrm{r}}(\dot{\varepsilon})$ have a reverse course a decrease in the values of $\sigma_{\text {fors }}$ and $\sigma_{\mathrm{r}}$ with an increase in the strain rate. A noticeable change in the slope of the deformation rate dependences of the strength properties is not found in a film with $\delta=25 \mu \mathrm{m}$, which retains sufficient elasticity at $4.2 \mathrm{~K}$. This allows us to assume the preservation of the mechanisms of shape change, characteristic at room temperature, up to $4.2 \mathrm{~K}$, but their flow is localized along the working part of the sample.

\section{CONCLUSION}

1. The characteristics of strength (forced elasticity limit $\sigma_{\text {fors }}$ and rupture stress $\sigma_{\mathrm{r}}$ ) and deformability (relative deformation before fracture $\varepsilon$ ) of three polyimide films of the kapton $\mathrm{H}$ type (made in China) of different thickness 
$(25,75$ and $125 \mu \mathrm{m})$ in the temperature range $4.2-293 \mathrm{~K}$ and strain rates $10^{-5}-10^{-3} \mathrm{~s}^{-1}$. The significant hardening of the films with a decrease in temperature to $4.2 \mathrm{~K}$ was discovered.

2. It was found that the deformation curves of films with a thickness of 75 and $125 \mu \mathrm{m}$ have two stages at all temperatures and strain rates: linear and nonlinear. On the $(\sigma-\varepsilon)$ curves of a $25-\mu \mathrm{m}$-thick film at 293 and $77 \mathrm{~K}$, three stages are observed: a linear and two nonlinear ones with different hardening coefficients, and at $4.2 \mathrm{~K}$, two types of curves are observed - with a small and large stage of nonlinear deformation proceeding jumpily.

3. It has been established that the brittleness temperature $T_{b r}$ is not reached $\left(\sigma_{\text {fors }}<\sigma_{\mathrm{r}}\right)$ for films of all thicknesses at investigation temperatures and strain rates. The minimum elasticity level for all films is similar, and the temperature at which it is reached depends on the film thickness. It occurs for a film with a thickness of $125 \mu \mathrm{m}$ at $77 \mathrm{~K}$, for a film with a thickness of $75 \mu \mathrm{m}$ and samples of a $25 \mu \mathrm{m}$ film with a short nonlinear stage - at $4.2 \mathrm{~K}$.

4. Necks in the fractures of the film samples in the plane of the film, the presence of which depends on the thickness and temperature were found. Necks are observed in all films at all strain rates at room temperature. With a decrease in temperature, only in thinnest film samples.

5. For the first time, a deformation relief in the form of shear bands associated with the localization of deformation at low temperatures was observed. The presence of a relief, the temperature of its appearance and the area of the working part of the sample occupied by it depend on the thickness of the film. The relief at a small film thickness can be caused by two different processes: irreversible processes of formation and development of cracks and reversible processes of orientation of segments of polymer molecules.

6. For the first time, it has been established that the strain rate sensitivity of the strength properties depends on the film thickness both in magnitude and in character at low temperatures. It was found that the character of the rate sensitivity of the $\sigma_{\text {fors }}$ and $\sigma_{\text {fors }}$ limits changes to the opposite at $4.2 \mathrm{~K}$ in more ordered thick films $(75$ and $125 \mu \mathrm{m})$ and that the character of the $\sigma_{\text {fors }}(\dot{\varepsilon})$ and $\sigma_{\mathrm{r}}(\dot{\varepsilon})$ dependences remains up to $4.2 \mathrm{~K}$ in the most amorphous thin film $(25 \mu \mathrm{m})$.

The authors are grateful to V.D. Natsik for his interest in the topic discussed in the article, for the comments and additions expressed during its discussion.

\section{ORCID IDs}

(D)Viktory A. Lototskaya, https://orcid.org/0000-0001-8766-3154; DLeonid F. Yakovenko, https://orcid.org/0000-0003-0001-5571; (D)Evgeniy N. Aleksenko, https://orcid.org/0000-0002-6505-0426

\section{СПИСОК ЛИТЕРАТУРЫ}

[1] M.I. Bessonov, M.M. Koton, V.V. Kudryavtsev, and 1.A. Layus, Полііміди - клас термостійких полімерів [Роlyimides class of heat-resistant polymers], (Nauka, Leningrad, 1984), pp. 328. (in Russian).

[2] G.M. Bartenev, and Yu.S. Zuev, Міцність та руйнування високоеластичних матеріалів [Strength and rupture of highly elastic materials], (Himiyu, Moscow, 1964), pp. 335. (in Russian)

[3] V.V. Abraimov, N.N. Agashkova, L. Bone, I.V. Budnyak, N.I. Velichko, A.V. Krevsun, V.I. Kostenko, F. Lura, and A.M. Markus, Kosm. nauka tehnol. 1(1), 57-68 (1995), https://doi.org/10.15407/knit1995.01.057. (in Russian).

[4] V.P. Soldatov, G.I. Kirichenko, V.V. Abraimov, I.S. Braude, and V.G. Geidarov, Low Temperature Physics, 42, 817 (2016), https://doi.org/10.1063/1.4963917.

[5] V.A. Lototskaya, L.F. Yakovenko, E.N. Aleksenko, V.V. Abraimov, and Wen Zhu Shao, East. Eur. J. Phys. 4, 44-52 (2017), https://doi.org/10.26565/2312-4334-2017-2-06.

[6] V.G. Geidarov, I.S. Braude, N.N. Gal'tsov, Yu.M. Pohribnaya, V.A. Lototskaya, and N.A. Aksenova, Structural Studies of $\begin{array}{lllllll}\text { Polyimide Films. Size } & \text { Effect, } & \text { Nano } & \text { Studies, } & 11-14 & \text { (2019) }\end{array}$ http://dspace.nplg.gov.ge/bitstream/1234/312051/1/Nano_Studies_2019_N19.pdf.).

[7] Ye.G. Lur'e, L.G. Kazaryan, E.L. Uchastkina,V.V. Kovriga, K.N. Vlasova, M.L. Dobrokhotova, L.N. Yemel'yanova, Polymer Science U.S.S.R. 13(3), 685-692 (1971), https://doi.org/10.1016/0032-3950(71)90033-5.

[8] E.G. Lur'e, and V.V. Kovriga, Polymer Mechanics, 13, 496-501 (1977), https://doi.org/10.1007/BF00859325.

[9] V.P. Pshenitsyna, L.G. Kazaryan, Ye.G. Lur'ye, M.L. Lebedinskaya, and V.V. Kovriga, The spectroscopic study of polyimide film deformations, Polymer Science U.S.S.R. 14(3), 702-707 1972, https://doi.org/10.1016/0032-3950(72)90242-0.)

[10] L.M. Volikova, and V.K. Chernetskiy, in: Прикладне кріогенне і вакуумне матеріалознавство [Аpplied cryogenic and vacuum material science], (Naukova dumka, Kyiv, 1991), pp. 137-143. (in Russian)

\section{ЗАКОНОМІРНОСТІ НИЗЬКОТЕМПЕРАТУРНОЇ ДЕФОРМАЦЇ̈ ПОЛІМІДНИХ ПЛІВОК ТИПУ КАРТОN Н} РІЗНОЇ ТОВЩИНИ

\section{В.О. Лотоцька ${ }^{a}$, Л.Ф. Яковенко ${ }^{a}$, Є.М. Алексенко ${ }^{a}$ В.В. Абраімов ${ }^{b}$, Вень Чжу Шао $^{b}$}

${ }^{a}$ Фізико-технічний інститут низьких температур ім. Б.І. Вєркіна Національної академії наук Украӥни пр. Науки, 47, м. Харків, 61103, Україна

${ }^{b}$ Харбінський Політехнічний інститут, м. Харбін, КНР

Досліджено механічні характеристики поліімідних плівок (границя вимушеної еластичності $\sigma_{в}$, напруга руйнування $\sigma_{\mathrm{p}}$, відносна деформація до руйнування $\varepsilon_{\mathrm{p}}$ ) типу kapton $\mathrm{H}$ (виробництва КНР) в умовах одноосьового розтягу вздовж напрямку витяжки в диапазоні температур (4,2-293 К), швидкостей деформації $\left(10^{-5}-10^{-3} \mathrm{c}^{-1}\right)$ та товщін плівки $(25,75$ й 125 мкм). Виявлено, що аж до 4,2 К при всіх швидкостях деформації у всіх плівок зберігається вимушено-еластичний стан - $\sigma_{\mathrm{B}}<\sigma_{\mathrm{p}}$. 
При цьому запас еластичності при зниженні температури істотно залежить від товщини плівки. Різке зниження $\varepsilon_{\mathrm{p}}$ відбувається в плівках: товщиною 125 мкм - при 77 К, товщиною 75 мкм - при 4,2 К. У плівці товщиною 25 мкм при 4,2 К можливі два варіанти деформаційних кривих - 3 короткою нелінійної або з довгою стадією, що протікає стрибкоподібно. Робоча поверхня зразків, що зазнали стрибкоподібну деформацію, покрита деформаційним рельєфом, який частково представляє затриману високоеластичну деформацію. Границя бв найбільш чутлива до швидкості деформації. Характер швидкісний чутливості $\sigma_{\mathrm{B}}(\dot{\varepsilon})$ залежить від температури і товщини плівки. Вперше виявлено зміна характеру $\sigma_{\text {в }}(\dot{\varepsilon})$ на протилежний в плівках товщиною 75 і 125 мкм при зниженні температури до 4,2 К. У плівці товщиною 25 мкм, що зберігає максимальний запас еластичності при $4,2 \mathrm{~K}$, зміни характеру $\sigma_{\mathrm{B}}(\dot{\varepsilon})$ не спостерігається.

КЛЮЧОВІ СЛОВА: полііміди, низькі температури, границя змушеної еластичності, напруга руйнування, деформація

\section{ЗАКОНОМЕРНОСТИ НИЗКОТЕМПЕРАТУРНОЙ ДЕФОРМАЦИИ И РАЗРУШЕНИЯ ПОЛИИМИДНЫХ ПЛЕНОК ТИПА КАРТОN Н РАЗЛИЧНОЙ ТОЛЩИНЫ \\ В.А. Лотоцкая ${ }^{\mathrm{a}}$, Л.Ф. Яковенко ${ }^{\mathrm{a}}$, Е.Н. Алексенко ${ }^{\mathrm{a}}$, В.В. Абраимов ${ }^{\mathrm{b}}$, Вень Чжу Шао $^{\mathrm{b}}$}

${ }^{a}$ Физико-технический институт низких температур им. Б.И. Веркина Национальной академии наук Украинь пр. Науки, 47, г. Харьков, 61103, Украина

${ }^{b}$ Харбинский Политехнический институт, г. Харбин, КНР

Исследованы механические характеристики (предел вынужденной эластичности $\sigma_{\mathrm{s}}$, напряжение разрушения $\sigma_{\mathrm{p}}$, относительная деформация до разрушения $\varepsilon_{\mathrm{p}}$ ) полиимидных пленок типа kapton $\mathrm{H}$ (производства КНР) в условиях одноосного растяжения вдоль направления вытяжки в диапазоне температур (4,2-293 К), скоростей деформации $\left(10^{-5}-10^{-3} \mathrm{c}^{-1}\right)$ и толщин пленки $(25,75$ и 125 мкм). Обнаружено, что вплоть до 4,2 К при всех скоростях деформации у всех пленок сохраняется вынужденно-эластическое состояние - $\sigma_{\mathrm{B}}<\sigma_{\mathrm{p}}$. При этом запас эластичности при снижении температуры существенно зависит от толщины пленки. Резкое снижение $\varepsilon$ происходит в пленках: толщиной 125 мкм при 77 К, толщиной 75 мкм - при 4,2 К. В пленке толщиной 25 мкм при 4,2 К возможно два варианта деформационных кривых - с короткой нелинейной или с длинной стадией, протекающей скачкообразно. Рабочая поверхность образцов, претерпевших скачкообразную деформацию, покрыта деформационным рельефом, частично представляющим задержанную

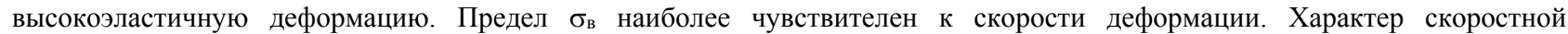
чувствительности $\sigma_{в}(\dot{\varepsilon})$ зависит от температуры и толщины пленки. Впервые обнаружено изменение характера $\sigma_{\text {в }}(\dot{\varepsilon})$ и $\sigma_{\mathrm{p}}(\dot{\varepsilon})$ на противоположный в пленках толщиной 75 и 125 мкм при понижении температуры до 4,2 К. В пленке толщиной 25 мкм, сохраняющей максимальный запас эластичности при $4,2 \kappa$, изменения характера $\sigma_{\mathrm{B}}(\dot{\varepsilon})$ не наблюдается.

КЛЮЧЕВЫЕ СЛОВА: полиимиды, низкие температуры, предел вынужденной эластичности, напряжение разрушения, деформация 